\title{
Assessing Employability Skills among Special Education Student Teachers in Malaysia
}

\author{
Zainudin Mohd Isa \& Ahmad Zamri Khairani \\ School of Educational Studies, 11800 Universiti Sains Malaysia, Penang, Malaysia \\ zainudin@usm.my
}

\begin{abstract}
The aim of this study is to assess employability skills among Special Education student teachers in Malaysia with regards to gender and years of study.. Employability skills is conceptualized by 8 generic skills namely, Communication, Critical Thinking, Adaptation, Teamwork, Leadership, Moral and Ethical, ICT and Social. A total of 258 student teachers who enrol in Special Education programme provide reponses for this study. Result shows that female student teachers demonstrate higher mean score for all skills with significant differences are reported for Critical Thinking, ICT, Leadership, Moral, and Social skills. Year 4 student teachers show lowest score in the employability skill as well as for Adaptation, Critical Thinking, Leadership, Moral, Social, Teamwork domains..
\end{abstract}

Keywords:Graduate employability, Special Education, student teachers, Malaysia

\section{INTRODUCTION}

Graduate employability does not depends solely on academic performance alone. Rather, it is also relies on other related skills (Beard, 2007; Wail, Ismail, \& Yussof, 2011). This is because employee's values and qualities are essential not only to maintain harmony at the workplace, but also help them to cope with rapid changes in the labour market (Raybould \& Sheedy, 2005; Cox \& King, 2006). More importantly, at present, employment is characterized as the following: usage of information process, excessive use of technology, high workforce emulation, extensive restructuring, smaller material size as well as on-going changes at workplace (Bakar \& Hanafi, 2007). Therefore, to cater to these charateristics, all employees need to acquire certain skills that enable them to function well in the workplace. These skills are known by many names such as employability skills, necessary skills, soft skills or key competencies (Clayton, Bloom, Meyers and Bateman, 2003).

In this paper we conceptualized these skills as employability skills. It includes personal image, attitudes, habits, and behavior such as leadership, teamwork, communication and continuous learning that are important for a quality employee. There is a growing interest in the study of employability skills in Malaysia. The skill has been identified as one of the core components in the Malaysia Education Blueprint 2013 - 2015 (Ministry of Education, 2013). According to the blueprint, education is an important platform to produce human capital with sstrong identity, competent, noble, knowledgeable and highly skilled that are able to think critically and creatively, have skills to solve problems, as well as the ability to create new opportunities, resilience and able to cope with sudden global changes.

There are also growing number of interest in research regarding employability among graduates in education program as well. Like other graduates, these graduates (called student teachers) are often face daunting challenges during their first year of teaching (Ministry of Education, 2006; Smith \& Ingersoll, 2004). According to Carpenter (2002), these challenges include inadequate or inappropriate training, lack of materials, non-teaching burdens and reality shock. Higdon (2005) adds that the student teachers are also lack ability to understand students' culture and backgrounds. As such, in order to meet these challenges, student teachers need to acquire important employability skills.
In Malaysia, employability among university undergraduates has been studied in various perspectives. With majority of the studies investigate the employers' perspective on the skills needed (Zaharim, Yusoff \& Omar, 2009; Hassan, Zaidi, Zainal, Abdullah, Badrulhisham, Hamid, Abdullah, Azmi \& Zaidi, 2007). However, there are also growing number of research that deal with employability skills among undergraduates such as Bakar and Hanafi (2007) for technical vocational undergraduatesand Amin, Jaafar, Hood, Saad and Amin (2013) for undergraduates from Faculty of Technology and Information Sciences. With regards to demographic variables, previous research in Malaysia focus on gender, work experience as well as comparison between undergraduates from different faculties. Results from these studies also differ with most of the studies show that the undergraduate lacks the employability skills (Rasul, Ismail, Ismail, Rajuddin \& Rauf, 2009). Among the skills that are lacking are communication, writing and ICT (Bax \& Mahmood, 2005) and problem solving (Amin, Jaafar, Hood, Saad and Amin, 2013). Suggestions from these studies include nurturing employability skills during teaching and learning especially for command in English and problem solving skills, proper monitoring of the skills as well as positif attitudes from the undergraduates. In addition,

\section{Problem Statement}

Student teachersin are considered fortunate since they are guaranteed placement to teach after graduation. Nevertheless, starting from 2013, the minister of education said that there are no more the student teachers. This is mainly because of the influx of undergraduates produced by both teacher education institutes as well as local public universities. In 2016 , the average employability rate were at $77.2 \%$. Based on the senario, there is a need for student teachers to no longer depend on the government to provide placement.

Nevertheless, for student teachers in Special Education programme, their study is very much tailored to the need of special education students, especially at the government schools. As such, they were trained mostly on skills that were related to the special need students, but not on other generic skills that are related to employment at other institutes such as hospitals, clinics, rehabilitation centres, etc. In addition, there is almost no information on employability skills of special education student teachers documented in Malaysia that can be used to explore other possible career for them. 


\section{The Aim of Research}

The aim of this research is to assess employability skills among Special Education student teachers at Universiti Sains Malaysia. The study provides information on skills that are lacking, and therefore provide opportunities for relevant stakeholders to suggest steps to enhance the skills.

\section{METHOD OF RESEARCH}

The present study employs quantitative approach using a sample of 258 special education student teachers at the Universiti Sains Malaysia. Demographic data of the sample is given in the following Table 1.

Table 1. Demographic information of the Sample

\begin{tabular}{|c|c|c|}
\hline & $\mathbf{N}$ & $\%$ \\
\hline \multicolumn{3}{|l|}{ Gender } \\
\hline Male & 35 & 3.57 \\
\hline Female & 223 & 86.43 \\
\hline \multicolumn{3}{|l|}{ Years of Study } \\
\hline First & 51 & 19.77 \\
\hline Second & 58 & 22.48 \\
\hline Third & 75 & 29.07 \\
\hline Final & 74 & 28.68 \\
\hline
\end{tabular}

All the student teachers enroll in teacher Special Education teacher education programme at the Universiti Sains Malaysia. This is a 4-year programme that aims to produce teachers that have knowledge and skill to address special needs students. In general, four areas of special needs covered by the programme are (1) learning disability, listening disability, (3) sight problem and (4) gifter and talented.

This study utilizes self-developed instrument to gauge responses from the student teachers. The instrument consists of 8 dimensions as depicted by the following Table 2. The instrument employs a six-point Likert scale, namely, Strongly Disagree, Disagree, Quite Disagree, Quite Agree, Agree and Strongly Agree. The data was analyzed using IBM SPSS Statistics 22 and statistics such as mean and standard deviation were reported. In adition, the present study also uses independent sample t-test to describe difference between male and female scores in the employability skills. ANOVA, meanwhile, is also employed to provide information on the difference in between Year1, Year 2, Year 3 and Year 4 students teachers.

Table 2. Dimensions of the Employability Skills

\begin{tabular}{|l|c|l|}
\hline \multicolumn{1}{|c|}{ Dimensions } & Item & \multicolumn{1}{|c|}{ Sample } \\
\hline Communication & 5 & $\begin{array}{l}\text { Deliver } \\
\text { information }\end{array}$ \\
\hline Critical Thinking & 5 & $\begin{array}{l}\text { Truthworthi-ness } \\
\text { of information }\end{array}$ \\
\hline Adaptation & 5 & $\begin{array}{l}\text { Adapt to unfimilar } \\
\text { situation }\end{array}$ \\
\hline Teamwork & 5 & $\begin{array}{l}\text { Working with } \\
\text { others }\end{array}$ \\
\hline Leadership & 5 & Give clear \\
\hline
\end{tabular}

\begin{tabular}{|l|c|l|}
\hline & & directions \\
\hline Moral \& Ethical & 6 & $\begin{array}{l}\text { Control emotion } \\
\text { and behaviour }\end{array}$ \\
\hline ICT & 6 & $\begin{array}{l}\text { Find information } \\
\text { through the } \\
\text { internet }\end{array}$ \\
\hline Social & 5 & $\begin{array}{l}\text { I am open to other } \\
\text { opinions }\end{array}$ \\
\hline Total & 2 & \\
\hline
\end{tabular}

\section{ANALYSIS AND DISCUSSION}

\section{gender.}

Employability skill according to

The present findings provide information on employability skills according to gender as depicted in Table 3. In general, the female undergraduates show higher mean scores in all skills compared to their male counterpart. Results from independent sample t-test (Table 4) shows that the mean different are significant for 4 of the skills, namely, Critical Thinking, ICT, Leadership, Moral, and Social. The significantly higher mean differences for the female undergraduates echoes various studies by Bakar and Hanafi (2007) as well as Amin, Jaafar, Hood, Saad and Amin (2013). More specifically, result for Critical Thinking dimension is in line with findings from Verawati, Ariffin, Idris and Hamid (2010) and Ghadi, Bakar, Alwi and Talib (2013). However, one important observation is that for ICT skills, the present study shows that female undergraduates demonstrate higher mean scores compared to their male counterpart. This is in contrast with other studies regarding ICT use between male and female such as by Lim and Amanda (2001) and Ariffin (2005), where male undergraduates are always considered more competent than the females.

Table 3. Mean Scores of the Employability Skills based on Gender

\begin{tabular}{|l|l|l|}
\hline & Male & Female \\
\hline Adaptation & 23.63 & 24.69 \\
\hline Comm. & 23.39 & 23.52 \\
\hline Critical think & 23.97 & 25.33 \\
\hline ICT & 26.79 & 28.34 \\
\hline Leadership & 23.11 & 24.40 \\
\hline Moral & 28.06 & 30.38 \\
\hline Social & 24.26 & 25.80 \\
\hline Teamwork & 24.57 & 25.79 \\
\hline Employability & 201.10 & 208.43 \\
\hline
\end{tabular}

Table 4. Independent Sample t-test

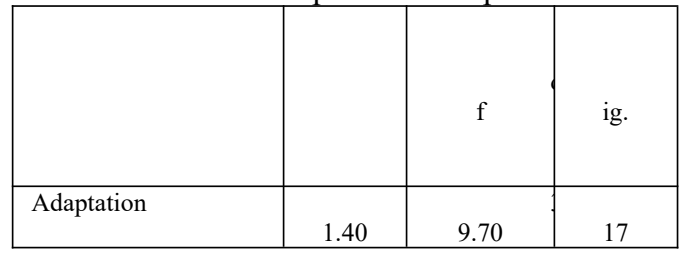




\begin{tabular}{|l|c|c|c|}
\hline Comm. & .20 & 53 & 84 \\
\hline Critical Think & 1.72 & 8.08 & 09 \\
\hline ICT & 2.16 & 52 & 03 \\
\hline Leadership & 2.24 & 53 & 03 \\
\hline Moral & 2.41 & 8.26 & 02 \\
\hline Social & 2.63 & 53 & 01 \\
\hline Teamwork & 1.58 & 8.81 & 12 \\
\hline Employability & 1.92 & 44 & 06 \\
\hline
\end{tabular}

lack of opportunity to provide assistance especially to enhance their employability skills.

In order to provide better understanding of the empirical data, further study should be conducted. This is because there is no similar study is documented previously to compare the result. Nevertheless, it is possible that since most of the respondents have no working experience before, they might inflate their scores. Meanwhile, the year 4 student teachers might have additional about reality in special education classes based on the courses attended such as teaching and learning for studnets with learning disabilities (PPK 311), listening abilities (PPK 312) or sight problems (PPK 313). In these courses, the student teachers are introduced to real scenario and challenges in classroom that may influence their perceptions about Special Education class as well as their efficacy on particular skills to

Table. 5 Employability skill according to years of study.

\begin{tabular}{|c|c|c|c|c|c|c|c|c|}
\hline & \multicolumn{2}{|c|}{ Year 1} & \multicolumn{2}{|c|}{ Year 2} & \multicolumn{2}{|c|}{ Year 3} & \multicolumn{2}{|c|}{ Year 4} \\
\hline & $\begin{array}{l}\mathrm{Me} \\
\text { an }\end{array}$ & D & $\begin{array}{l}\mathrm{Me} \\
\text { an }\end{array}$ & D & $\begin{array}{l}\mathrm{Me} \\
\text { an }\end{array}$ & D & $\begin{array}{l}\mathrm{Me} \\
\text { an }\end{array}$ & D \\
\hline $\begin{array}{l}\text { Adapta } \\
\text { tion }\end{array}$ & $\begin{array}{c}4.2 \\
5\end{array}$ & .99 & $\begin{array}{c}5.0 \\
5\end{array}$ & .84 & $\begin{array}{c}4.7 \\
7\end{array}$ & .98 & $\begin{array}{c}4.1 \\
1\end{array}$ & .35 \\
\hline Comm. & $\begin{array}{c}3.4 \\
8\end{array}$ & .29 & $\begin{array}{c}2.8 \\
4\end{array}$ & .56 & $\begin{array}{c}3.7 \\
9\end{array}$ & .28 & $\begin{array}{c}3.7 \\
4\end{array}$ & .97 \\
\hline $\begin{array}{l}\text { Critical } \\
\text { Think }\end{array}$ & $\begin{array}{c}4.7 \\
5\end{array}$ & .86 & $\begin{array}{c}5.6 \\
0\end{array}$ & .08 & $\begin{array}{c}5.5 \\
5\end{array}$ & .66 & $\begin{array}{c}4.6 \\
6\end{array}$ & .93 \\
\hline ICT & $\begin{array}{c}7.2 \\
8\end{array}$ & .85 & $\begin{array}{c}7.9 \\
3\end{array}$ & .56 & $\begin{array}{c}9.1 \\
4\end{array}$ & .46 & $\begin{array}{c}7.8 \\
9\end{array}$ & .34 \\
\hline $\begin{array}{l}\text { Leaders } \\
\text { hip }\end{array}$ & $\begin{array}{c}4.0 \\
2\end{array}$ & .53 & $\begin{array}{c}4.3 \\
1\end{array}$ & .93 & $\begin{array}{c}4.8 \\
6\end{array}$ & .16 & $\begin{array}{c}3.6 \\
8\end{array}$ & .11 \\
\hline Moral & $\begin{array}{c}9.9 \\
4 \\
\end{array}$ & .01 & $\begin{array}{c}0.2 \\
8\end{array}$ & .39 & $\begin{array}{c}0.8 \\
4\end{array}$ & .35 & $\begin{array}{c}9.2 \\
0\end{array}$ & .67 \\
\hline Social & $\begin{array}{c}5.3 \\
6\end{array}$ & .17 & $\begin{array}{c}6.5 \\
2\end{array}$ & .74 & $\begin{array}{c}5.7 \\
6\end{array}$ & .86 & $\begin{array}{c}4.8 \\
2\end{array}$ & .16 \\
\hline $\begin{array}{l}\text { Teamw } \\
\text { ork }\end{array}$ & $\begin{array}{c}5.8 \\
0\end{array}$ & .85 & $\begin{array}{c}6.0 \\
3\end{array}$ & .80 & $\begin{array}{c}6.0 \\
0\end{array}$ & .61 & $\begin{array}{c}4.8 \\
1\end{array}$ & .38 \\
\hline $\begin{array}{l}\text { Employ } \\
\text { ability }\end{array}$ & $\begin{array}{l}08 . \\
04\end{array}$ & $\begin{array}{c}9.7 \\
3\end{array}$ & $\begin{array}{c}08 . \\
09\end{array}$ & $\begin{array}{c}8.7 \\
8\end{array}$ & $\begin{array}{l}11 . \\
36\end{array}$ & $\begin{array}{c}8.7 \\
9\end{array}$ & $\begin{array}{l}02 . \\
94\end{array}$ & $\begin{array}{c}1.7 \\
5\end{array}$ \\
\hline
\end{tabular}

Table 5 demonstrates mean score for employability skills based on year of study. In general, it is quite a surprise when year 4 student teachers demonstrate the lowest employability mean score of 202.94, followed by year 1 (208.04), year 2 (208.09) and year 3 (211.36). In fact, the year 4 student teachers demonstrate the lowest score for majority of the skills, namely, Adaptation, Critical Thinking, Leadership, Moral, Social, Teamwork as well as the overall Employability skills. The finding is considered as alarming since they are in their final year of study, they will enter labour market once they completed their study. As such, university has deal with the challenges.

\section{CONCLUSION}

The present study is able to provide several information regarding employability skills among Special Education student teachers at the Universiti Sains Malaysia. Firstly, the female student teachers outscored their male counterpart in all skills with significant different were reported for Critical Thinking, ICT, Leadership, Moral, and Social skills. Secondly, Year 4 student teachers demonstrate the lowest mean score of employability skills, particularly in the Adaptation, Critical Thinking, Leadership, Moral, Social, Teamwork domains.

It limit notwithstanding, the present study should able to inform relevant stakeholders at university level to understand and nurture employability skills among the undergraduates with special attention for Year 4 students. This may be conducted as so-called 'finishing school' program, where specific employability skills which are essential for their line of job are conducted to equip the undergraduates to enable them to stand tallest among job seekers. Meanwhile, the undergraduates, on their part, also need to learn and relearn employability skills that are essential for their future. In addition they are also need to have positive attitudes towards employment especially during the challenging period.

\section{Acknowledgements}

The research is made possible from the funding of Short Term Grant from the Universiti Sains Malaysia (304/PGURU/6313270).

\section{REFERENCES}

Amin, H. M., Jaafar, J., Hood, Z., Saad, S. \& Amin, H. M. (2013). Kemahiran insaniah pelajar prasiswazah: Analisis perbezaan jantina. Jurnal Teknologi. 61(1): 19-25.

Ariffin, T. F. T., 2005. Gender differences in computer attitudes and skills. Jurnal Pendidikan. 30: 75-91.

Bakar, A. R. \& Hanafi, I. (2007). Assessing employability skills of technical-vocational students in Malaysia. Journal of Social Sciences. 3 (4): 202-207 
Bax, M. R. N. \& Mohamood, M. R. (2005). The Year 2004 Polytechnic Convocation Survey. Proceedings of National Seminar The Development of Technology and Technical-Vocational Education and Training in an Era of Globalization: Trend and Issues. Kuala Lumpur

Beard, D., Schwieger, D. \& Surendran, K. (2007). Incorporating Soft Skills into Accounting and MIS Curricula. SIGMIS-CPR 07, April 19-21, St. Louis, Missouri, USA. ACM 978-1-59593-641-7/07/0004 179-185.

Clayton, B., Bloom. K., Meyers D. \& Bateman A. (2003). Accessing and certifying generic skills: What is happening in vocational education and training? State Arcade, South Australia: National Centre for Vocational Education Research Ltd.

Cox, S. \& D. King. 2006. Skill Sets: An Approach to Embed Employability in Course Design. University of Central England, Birmingham, UK. Jurnal Education and Training. 48(4): 262-274.

Carpenter, J.L. (2002). Struggles, strategies, settlements and survival: Case studies of three beginning teachers. (Doctoral dissertation). Retrieved from ProQuest Dissertations and Theses database. (UMI Number:3072241).

Ghadi, I. N., Bakar, K. A Alwi, N. H. \& Talib, O. (2012). Gender analysis of critical thinking disposition instrument among University Putra Malaysia undergraduate students. Recent Technological Advances in Education. 2: 27-30.

Hassan, B., Mohd Zaidi, O., Zainal, M., Abang Abdullah, A. A., Badrulhisham, A.A, Abdul Hamid, H., Nik Abdullah, N.M., Azmi, H. \& Zaidi, M.R. 2007. The Future of Engineering Education in Malaysia. Laporan oleh the Department of Institutions of Higher Education Management, Ministry of Higher Education, Malaysia.

Higdon, K.A., (2005). First-year teachers in unfamiliar territory: case studies of novice teachers in urban schools. (Doctoral dissertation). Retrieved from ProQuest Dissertations and Theses database.

Lim, K. F. \& Amanda, K., 2001. IT skills of university first year undergraduate students: Two 2001 matriculation cohorts. UniServe Science News. 18:

Ministry of Education (2013). Education Blueprint 20132025. (Kementerian Pendidikan Malaysia, Putrajaya, 2013).

Ministry of Higher Education \& Ministry of Education (2006). Professionalism readiness of novice teachers: suggested training module, Penerbitan Fakulti Pendidikan. UKM.

Raybould, J. \&Sheedy, V.(2005). Are graduates equipped with the right skills in the employability stakes? Journal of Industrial and Commercial Training. 37(5): 259-263.

Rasul, M. S. Ismail, M. Y., Ismail, N. Rajuddin, R. \& Rauf, R. A. 2009. Peranan Institusi Pendidikan Teknikal dalam Pemupukan Kemahiran "Employability" Pelajar. Jurnal Teknologi. 50(E) Jun 2009: 113-127

Smith, T. M., \& Ingersoll, R. M. (2004). What are the effects of induction and mentoring on beginning teacher turnover? American Educational Research Journal, 41(3), 681-714.

Verawati, Arifin, S. R., Idris, R. \& Hamid, N. A. A (2010). Gender analysis of MyCT (Malaysian Critical Thinking) instrument. Procedia Social and Behavioral Sciences. 7(C): 70-76.

Zaharim, A, Yusoff, Y. M. Omar, M. Z. (2009). \& Employers" Perceptions and Expectation toward Engineering Graduates: A Study Case. Proceedings of the 6th WSEAS International Conference on
Engineering Education, Rodos, Greece, July 22-24. ISSN: 1790-2769. ISBN: 978-960-474-100-7. 2329. 